\title{
Evaluation of the papermaking potential of Ailanthus altissima
}

\author{
Paulo J. T. Ferreira ${ }^{1, *}$, José A. F. Gamelas ${ }^{1}$, Maria G. V. S. Carvalho ${ }^{1}$, Gustavo V.
} Duarte $^{1}$, Jorge M. P. L. Canhoto ${ }^{2}$, Raphael Passas ${ }^{3}$

${ }^{1}$ Chemical Process Engineering and Forest Products Research Center - Chemical Engineering Department, University of Coimbra, Pólo II, R. Sílvio Lima, 3030-790 Coimbra, Portugal.

${ }^{2}$ Center for Functional Ecology - Department of Life Sciences, Ap. 3046, 3001-401 Coimbra, Portugal.

${ }^{3}$ Grenoble INP-LGP2 - 465 rue de la Papeterie - 38400 Saint Martin d'Hères, France

*paulo@eq.uc.pt (Paulo. J. Ferreira), Tel: 00351239798747 ; fax: 00351239798703

\begin{abstract}
In this work, Ailanthus altissima (tree-of-heaven) wood was analyzed for its chemical, morphological and papermaking properties. The A. altissima wood was cooked under kraft conditions using different active alkali charges and then handsheets were produced with the pulps having a kappa number of 16 . Based on structural, strength and optical data it was found that the kraft pulp of $A$. altissima is not suitable to be used alone for the production of printing and writing papers. Notwithstanding, the handsheets exhibit a favorable value of brightness in comparison to those produced from Eucalyptus globulus pulp (with similar kappa number). Therefore, the wood of $A$. altissima seems to have a good potential to be used as a partial substitute of the main raw material of the Portuguese pulp industry. In fact, the results showed that when beaten $E$. globulus and $A$. altissima pulps were mixed (50:50 w/w), the papermaking properties were comparable to those of beaten eucalypts kraft pulps. Therefore, the use of $A$. altissima wood seems promising for the production of uncoated wood-free papers, which has advantages both from an economical and environmental perspective.
\end{abstract}

Keywords: Ailanthus altissima, chemical composition, kraft cooking, papermaking properties 


\section{Introduction}

Ailanthus altissima (Mill.) Swingle (tree-of-heaven) is a member of the Simaroubaceae family. It is a fast growing dioecious species rapidly reaching $15 \mathrm{~m}$ of height in about 25 years depending upon the growth conditions. The species is native of the northern and central mainland of China, Taiwan and Japan, where trees can stand for 50 years or more, reaching up to $30 \mathrm{~m}$ of height and $1 \mathrm{~m}$ of diameter at breast height (Kowarik and Säumel, 2007; Little, 1979). It has spread from oriental countries throughout Europe and USA where it behaves like an invasive plant threatening ecosystems (Fryer, 2010). This is due mainly to its ability to propagate by sexual and asexual means, and also to the allelopathic chemicals it produces, hence inhibiting the growth of neighbor plants (De Feo et al., 2003; Motard et al., 2011). In Portugal this species can be found all over the country being used as an ornamental tree in gardens, parks and streets (Marchante et al., 2008). In addition, this tree has become a pest not only by outcompeting native vegetation, but by causing damage to roadways, sidewalks, sewer structures, and orchards, due to its extensive root system. The plant reproduces very easily since a single female tree can produce as many as 325,000 seeds per year, which are easily dispersed by the wind (Dirr, 2009). It prefers rich and moist soils but tolerates also poor and dry soils. Besides, tree-of-heaven tolerates air pollution and may be able to sequester some pollutants. For this reason, it has been widely planted in urban areas worldwide to reduce the environmental pollution (Ding et al., 2006a; Ding et al., 2006b; Kundu and Laskar, 2010).

Eucalypt is one of the most valuable resources for papermaking worldwide, Portugal being the European largest producer of uncoated wood-free papers based on Eucalyptus globulus kraft pulps, which are recognized for the high multi-purpose printing quality. 
However, due to the extensive use, scarceness, high prices in the market and distribution problems associated to eucalypt pulps, it is advantageous to find alternative wood resources. In this context, A. altissima seems to be an interesting tree to be tested. Recently, A. altissima has been delignified using alkaline glycerol (Kuçuk, 2005; Kuçuk and Dermibas, 1993). A pulp yield of 54.5\%, a delignification degree of $78.1 \%$ (after 9 hours of reaction at $478 \mathrm{~K}$ ) and a remaining cellulose content of $86 \%$ were obtained when $\mathrm{NaOH}$ was used as catalyst in the process. In this paper, the use of A. altissima wood for kraft pulping aiming to obtain pulps with valuable properties for papermaking is reported by the first time.

\section{Material and methods}

Since no plantations of $A$. altissima are available, wood of this species was collected at breast height from a tree in the Botanical Garden of the University of Coimbra. The tree was about 20 years old, which corresponds to half of its life span. The trunk had a $20 \mathrm{~cm}$ diameter, lower than that of older trees. The chips were air dried, screened (SCAN-CM 40) and ground (TAPPI Standard T 264) for their chemical composition analysis (lignin, carbohydrates, uronic acids, ash and extractives). Wood samples were macerated for the determination of the fibers morphological parameters.

A rotatory digester was used to cook $200 \mathrm{~g}$ (o.d.) of chips at $160^{\circ} \mathrm{C}$, with a heating rate of $1{ }^{\circ} \mathrm{C} / \mathrm{min}$. The liquid to wood ratio was $3.5: 1$ and the time at maximum temperature was 60 min. Four different cooks with active alkali charges of 14\%, 16\%, $18 \%$ and $20 \%$ (as $\mathrm{Na}_{2} \mathrm{O}$ ) were performed, always with a sulfidity of $28 \%$. After cooking, the total and screened yield was determined and the pulp with a kappa number 
of 16 was analyzed for its chemical composition (lignin, carbohydrates and extractives), intrinsic viscosity and fiber biometry.

For both the wood and pulp samples, the content in Klason and acid-soluble lignin was determined using T 222 om and T UM 250 TAPPI Standard methods, respectively. Carbohydrates were determined by hydrolysis of the extracted wood or pulp samples firstly with $72 \% \mathrm{H}_{2} \mathrm{SO}_{4}$ during $2 \mathrm{~h}$ at room temperature and then with $4 \% \mathrm{H}_{2} \mathrm{SO}_{4}$ during $4 \mathrm{~h}$ at boiling temperature, followed by separation of the sugars by high pressure liquid chromatography (HPLC), using a Knauer HPLC instrument with refractive index detector and a HPX-87P column from Bio-Rad ${ }^{\circledR}$. The eluent used was ultrapure water and the operating conditions were $0.6 \mathrm{ml} / \mathrm{min}$ and $80{ }^{\circ} \mathrm{C}$. The extractives (ethanol/toluene) and ash amount were obtained following the T $204 \mathrm{~cm}$ and the T 211 om TAPPI Standards, respectively. Uronic acids in woods were determined following a published procedure (Scott, 1979). A Jasco V-550 spectrophotometer was used for the absorbance measurements. Pulps viscosity and kappa number were determined according to SCAN-CM 15 and TAPPI Standard T $236 \mathrm{~cm}$, respectively.

The biometry of the fibers (mean fiber length, fiber length distribution, fines content and fibers coarseness) were evaluated with the OpTest HiRes Fiber Quality Analyzer (FQA), using very dilute sample suspensions. Average values for the fiber width and fiber wall thickness were evaluated by image analysis, by taking measurements in individual fibers, using a CCD camera coupled to a light microscope

A sample of E. globulus unbleached kraft pulp with a kappa number of 16 was obtained from a Portuguese mill for comparison purposes, and its chemical composition was determined as described above. 
UV-vis diffuse reflectance spectra of the pulps were recorded on a Jasco V-560 spectrophotometer with a Jasco ISV-469 integrating sphere using $\mathrm{BaSO}_{4}$ standard as background reference. The acquisition was done in the range of 200-800 $\mathrm{nm}$ with a scanning speed of $100 \mathrm{~nm} /$ min and a bandwidth of $5 \mathrm{~nm}$. The reflectance spectra were converted into $k / s$ spectra using the Kubelka-Munk equation ( $k$ stands for the specific absorption coefficient and $s$ is the specific scattering coefficient). Pellets for analysis were prepared by pressing approximately $300 \mathrm{mg}$ of ground pulp for $2 \mathrm{~min}$ at $40 \mathrm{MPa}$.

Handsheets with a basis weight of $65 \mathrm{~g} / \mathrm{m}^{2}$ were prepared accordingly to the TAPPI Standard T 205, using both the A. altissima and E. globulus kraft pulps with 16 kappa number. Afterward, structural (thickness, bulk, air resistance (Gurley), and roughness (Bendtsen), optical (R457 C brightness, light scattering and opacity), and mechanical properties (tensile index, tensile stiffness, elongation, Scott bond, burst index, tear index) were determined following the corresponding TAPPI Standards. Pulps drainability was also determined. Handsheets with PFI beaten pulps (having a SR close to 30) were also produced and the aforementioned properties were evaluated.

\section{Results and Discussion}

\subsection{Chemical Composition and Fibers Biometry of Ailanthus altissima Wood}

The amounts of extractives, lignin (Klason, acid-soluble and total lignin), cellulose, hemicelluloses and ash determined for A. altissima wood are presented in Table 1. Typical data for E. globulus are also presented for comparison and are in reasonable agreement with others reported in the literature for this wood species (Pinto et al., 2005). 
The values for Klason lignin and total lignin are slightly lower than those reported by Khattak and Ghazi (2001) and Kuçuk (2005): 22.5 and 26.5\%, respectively. On the other hand, the extractives content $(\approx 2 \%)$, is similar to that found for this wood by Kuçuk (2005). As for the carbohydrate composition of A. altissima wood, it has not yet been reported in the literature and thus no comparison can be made. When compared to E. globulus wood, the A. altissima wood presents a smaller amount of total lignin, mostly due to the lower value of the acid-soluble lignin, but a larger amount of ash. Regarding polysaccharides, higher content of cellulose and galactan and lower content of xylan and glucomannan are found in A. altissima wood. Uronic acids and arabinnan contents are similar for both woods.

Please, Insert table 1

Concerning the fiber morphology analysis for the A. altissima wood the average fiber length determined is $0.74 \mathrm{~mm}$ for $\mathrm{L}_{1}$ (length weighted) and $0.54 \mathrm{~mm}$ for $\mathrm{L}_{\mathrm{n}}$ (number weighted), the fiber width and the fiber wall thickness are approximately 20 $\mu \mathrm{m}$ and $4 \mu \mathrm{m}$, respectively. The length and fiber width values are not far from those previously found for the same species by Khattak and Ghazi (2001): $0.89 \pm 0.2 \mathrm{~mm}$, $21.05 \pm 1.88 \mu \mathrm{m}$ and $2.43 \pm 0.3 \mu \mathrm{m}$, respectively for $\mathrm{L}_{1}$ fiber length, width and wall thickness.

\subsection{Pulp Characterization}

The results of the different cooks of A. altissima wood chips are presented in Table 2. As expected, it was found that the increase of the active alkali charge (from 14 to $20 \%$ as $\mathrm{Na}_{2} \mathrm{O}$ basis) leads to a decrease of the pulps kappa number, ranging from 21.6 to 
12.6. The pulp yields were in the range of 52 to $55 \%$ being comparable to those of $E$. globulus kraft cookings (Carvalho et al., 2003).

Please, Insert table 2

The chemical analyses of the A. altissima pulp selected for the subsequent papermaking tests (Table 3) show that this pulp presents higher cellulose and lower xylan content than the E. globulus pulp for the same kappa number. The residual lignin content and the pulp intrinsic viscosity are similar for both pulps. Therefore the selectivity of both cooking processes expressed in terms of pulp viscosity/residual lignin is comparable.

\section{Please, Insert table 3}

As for the fiber morphology, it is clear from Table 4 that the A. altissima kraft pulp fibers are longer and larger than those of E. globulus and, in agreement, have a larger wall thickness, a higher coarseness, a higher Runkel index and a smaller number of fibers per gram. They also exhibit a considerably higher amount of fines. These differences will be reflected in the beatability and the papermaking properties, as discussed next.

\section{Please, Insert table 4}

\subsection{Papermaking properties}

The properties of the handsheets prepared with the A. altissima and industrial $E$. globulus kraft pulps with kappa 16 are presented in Table 5.

As can be seen, the drainability of the unbeaten A. altissima pulp is higher than that of the E. globulus pulp, in agreement with the higher values of the fibers coarseness, width and wall thickness, which reduce the fibers flexibility and colapsability and, therefore, increases the porosity of the fiber mat. The results also reveal that the effect 
of the smaller conformability of the A. altissima fibers in the drainability is higher than the effect of the higher fines content of the pulp. The values of the handsheets bulk, air resistance and roughness, for the unbeaten pulps, are also a consequence of the fibers morphology and of the resultant more open structure of the fibers matrix.

Regarding the strength properties, it is clear that the unbeaten A. altissima fibers have a reduced bonding ability, in accordance with the aforementioned smaller conformability. In addition, due to the higher rigidity of the fibers, the beating time (in terms of PFI rev.), necessary to reach a Schopper-Riegler degree (SR) close to that of the eucalyptus pulp corresponding to a tensile index of approximately $70 \mathrm{Nm} / \mathrm{g}$, is much higher. Besides, the smaller xylan content of the A. altissima pulp and hence the inferior swelling ability of the fibers is also detrimental for its beatability.

Please, Insert table 5

It should be mentioned the significantly higher reflectance at $457 \mathrm{~nm}$ of the $A$. altissima kraft pulp, compared to that of the E. globulus pulp, which is an important feature for the subsequent bleaching treatment and paper optical properties. Further confirmation comes from the UV-vis electronic reflectance spectra of Figure 1. In fact, the $k / s$ spectrum of $A$. altissima pulp shows much lower absorption in all the visible range, including the wavelength of $457 \mathrm{~nm}$, when compared to that of E. globulus pulp. Besides, in the UV region, A. altissima presents an absorption maximum at $335 \mathrm{~nm}$ while E. globulus shows the absorption maxima at 340 and $370 \mathrm{~nm}$ (the latter is very close to that of $365 \mathrm{~nm}$ reported for Eucalyptus kraft lignin (Loureiro et al., 2011). Thus, since the bands with maxima at $\lambda \geq 300 \mathrm{~nm}$ are due to the presence of chromophore groups in lignocellulosic pulps (Loureiro et al., 2011) a lower amount is 
anticipated for A. altissima, which should be responsible for the higher brightness exhibited by this pulp.

\section{Please, Insert Figure 1}

With refining it is expected that the E. globulus fibers develop internal fibrillation better than the A. altissima fibers, due to the higher amount of hemicelluloses. For the stiff $A$. altissima fibers, external fibrillation and cutting are expected to be the dominant refining effects. As a consequence of these phenomena and of the more extensive beating operation, the predictable reduction of bulk, roughness and air resistance is much more pronounced for the A. altissima, and thus the beaten pulp exhibits values close to those of the E. globulus beaten pulp (contrary to the unbeaten pulps). Also the strength properties of the A. altissima pulp are considerably developed with refining but, even though, the handsheets mechanical resistance remains below the one of the $E$. globulus beaten pulp. This is most probably a result of the weaker internal fibrillation and of the smaller xylan content, which are recognized to play an important role on the fibers flexibility and bonding ability (Laine et al., 1997; Paavilainen, 1994). The exceptions are the tensile stiffness and the handsheets internal resistance (evaluated by the Scott Bond test), probably due on the one hand to the influence of the fibers rigidity and on the other hand to the effect of the external fibrillation. Both light scattering and opacity decrease with refining, as expected, being the variation of the A. altissima pulp more noticeable. The values of these two properties are even inferior to those of the $E$. globulus beaten pulp, as well as the value of bulk, confirming that the A. altissima handsheets are slightly less porous, probably due to the dominant effects of external fibrillation and cutting, which promote fines formation. These fines play a relevant filling role but their impact on the strength properties is scarce. 
In spite of the weak strength properties of the A. altissima pulps it was decided to mix them with the E. globulus pulps in order to evaluate the papermaking potential of the resulting blend. Therefore, a 50:50 (w/w) mixture of the beaten pulps of both species was prepared. The properties of the corresponding handsheets are also presented in Table 5. As it is clear, the strength properties are almost as good as those of the $E$. globulus beaten pulp handsheets (the internal bond - Scott Bond test - is even considerably better) and a not relevant variation of bulk, opacity and light scattering is found. However, as for brightness, the aimed positive influence of the A. altissima beaten fibers was not detected, since the final value is close to the one of the original $E$. globulus beaten pulp. Even so, it is interesting to conclude that the substitution of half of the E. globulus beaten pulp furnish by an equal amount of A. altissima beaten pulp is not harmful for the papermaking properties which are important for the common end use of the eucalyptus kraft pulps - the production of printing and writing fine papers. Nonetheless, it must be stressed that, as revealed by this study, the refining energy necessary to enhance the papermaking potential of the A. altissima stiff fibers is too high, if compared to that of the E. globulus pulps for a similar refining degree.

Nevertheless, the results obtained are promising and show that there is room to keep on with this research. On the one hand the use of less refining energy for the $A$. altissima kraft pulps (and, consequently, a smaller degradation of the fibers) should be tested, as well as refining together mixtures of unbeaten A. altissima and E. globulus kraft pulps, trying simultaneously blends with distinct contents of both pulps. Bleaching performance needs also to be studied, in face of the much better brightness of the $A$. altissima kraft pulp fibers. The smaller content of hemicelluloses of these fibers, and the 
subsequent detrimental effect on their bonding ability, can also be somehow overcome by adding hydrophilic polymers like starch, during the papermaking process.

\section{Conclusions}

Ailanthus altissima wood exhibits a lower amount of lignin and xylan and a higher amount of cellulose, when compared to E. globulus wood. The corresponding kraft pulps with kappa number of 16 have similar lignin content but $A$. altissima pulp exhibits also a higher cellulose/xylan ratio.

Ailanthus altissima pulp fibers are longer, wider and have also a larger wall thickness than E. globulus fibers.

The handsheets prepared with A. altissima unbeaten kraft pulp (kappa number of 16), exhibit mechanical properties significantly worse than those of E. globulus unbeaten pulp handsheets, namely tensile index, elongation, Scott bond, burst index and tear index. However, the brightness of A. altissima is significantly higher, which is an advantage for papermaking.

The strength properties of the A. altissima pulp are considerably improved with refining, although they remain below those of the E. globulus beaten pulp for similar SR (except the tensile stiffness and the handsheets internal resistance).

When mixtures 50:50 (w/w) of beaten E. globulus and A. altissima pulps are used for the production of handsheets the results regarding strength properties are similar to those obtained with beaten (750 rev) E. globulus pulp alone. As for brightness, the positive influence of the A. altissima beaten fibers was somewhat diminished in the 
mixtures, since the final value is more close to the one of the original E. globulus beaten pulp.

The use of A. altissima wood can be an alternative to partially reduce the dependence of other species such as E. globulus for papermaking. The lower amount of xylan in A. altissima pulps and its negative effect in handsheets strength properties can be possibly overcome by adding appropriate amounts of polymers with binding properties like starch, during the papermaking process.

\section{References}

Carvalho, M.G.V., Martins, A.A., Figueiredo, M.M.L., 2003. Kraft pulping of Portuguese Eucalyptus globulus: effect of process conditions on yield and pulp properties. Appita J. 56, 267-274.

De Feo, V., De Martino, L., Quaranta, E., Pizza, C., 2003. Isolation of phytotoxic compounds from tree-of-heaven (Ailanthus altissima Swingle). J. Agric. Food Chem. $26,1177-1180$.

Ding, J., Reardon, R., Wu Y., Zheng, H., Fu W., 2006a. Biological control of invasive plants through collaboration between China and the United States of America: a perspective. Biol. Invasions 8, 1439-1450.

Ding, J., Wu, Y., Zheng, H., Weidong, F., Reardon, R., Liu, M., 2006b. Assessing potential biological control of the invasive plant, tree-of-heaven Ailanthus altissima. Biocontrol Sci. Technol. 16, 547-566.

Dirr, M.A., 2009. Manual of woody landscape plants: their identification, ornamental characteristics, culture, propagation and uses. Stipes Publishing L.L.C., 6th ed., Champaign, USA. 
Fryer, J.L., 2010. Ailanthus altissima. In: Fire Effects Information System, [Online]. U.S. Department of Agriculture, Forest Service, Rocky Mountain Research Station, Fire Sciences Laboratory (Producer). URL: http://www.fs.fed.us/database/feis/. Accessed February 2012.

Khattak, T.M., Ghazi, J., 2001. Suitability of some non-commercial fast growing wood yielding trees growing in Azad Kashmir for the production of pulp and paper. Pak. J. Bot. 33, 266-269.

Kowarik, I., Säumel I., 2007. Biological flora of Central Europe: Ailanthus altissima (Mill.) Swingle. Perspect. Plant Ecol. Evol. Syst. 8, 207-237.

Kuçuk, M.M., 2005. Delignification of biomass using alkaline glycerol. Energy Sources Part A-Recovery Util. Environ. Eff. 27, 1245-1255.

Kuçuk, M.H., Demirbas A., 1993. Delignification of Ailanthus altissima and SpruceOrientalis with glycerol or alkaline-glycerol at atmospheric pressure. Cell. Chem. Technol. 27, 679-686.

Kundu, P., Laskar, S., 2010. A brief resume on the genus Ailanthus: chemical and pharmacological aspects. Phytochem. Rev. 9, 379-412.

Laine, J., Hynynen, R., Stenius, P., 1997. The effect of surface chemical composition and charge on the fibre and paper properties of unbleached and bleached kraft pulps. In: Baker, C. F. (Ed.), Proc. Fundamental Research Symposium - The Fundamentals of Papermaking Materials, Pira International, Surrey, England, Vol. 2, 859-892.

Little, E.L., Jr., 1979. Checklist of United States trees (native and naturalized). U.S. Department of Agriculture, Agriculture Handbook 541, Washington, USA.: 
Loureiro, P.E.G., Fernandes, A.S.G., Furtado, F.P., Carvalho, M.G.V.S, Evtuguin, D.V., 2011. UV-resonance Raman micro-spectroscopy to assess residual chromophores in cellulosic pulps. J. Raman Spectrosc. 42, 1039-1045.

Marchante, E., Freitas, H., Marchante, H., 2008. Guia prático para a identificação de plantas invasoras de Portugal continental. University of Coimbra (ed.), Coimbra, Portugal.

Motard, E., Muratet, A., Clair-Maczulajtys, D., Machon, N., 2011. Does the invasive species Ailanthus altissima threaten floristic diversity of temperate peri-urban forests? C. R. Biol. 334, 872-879.

Paavilainen, L., 1994. Influence of fibre morphology and processing on the papermaking potential of softwood sulphate pulp fibres. Proc. Pulping Conference, San Diego, USA, Vol. 2, 857-867.

Pinto, P.C., Evtuguin, D.V., Neto, C.P., 2005. Effect of structural features of wood biopolymers on hardwood pulping and bleaching performance. Ind. Eng. Chem. Res. 44, 9777-9784.

Scott, R.W., 1979. Colorimetric determination of hexuronic acids in plant materials. Anal. Chem. 51, 936-941. 
Table 1. Chemical composition of A. altissima and E. globulus woods

\begin{tabular}{lll}
\hline Components (\% w/w, on o.d. wood) & A. altissima & E. globulus \\
\hline Extractives (ethanol/toluene) & 1.8 & 1.1 \\
Klason lignin & 21.2 & 20.9 \\
Acid-soluble lignin & 2.4 & 4.8 \\
Total lignin & 23.6 & 25.7 \\
Cellulose & 49.7 & 45.5 \\
Xylan $^{\mathrm{a}}$ & 12.6 & 14.8 \\
Glucomannan $^{\mathrm{b}}$ & 0.6 & 1.5 \\
Galactan $_{\text {Arabinnan }}$ & 4.1 & 1.5 \\
Uronic acids & 0.6 & 0.5 \\
Ash content & 6.6 & 6.2 \\
\hline
\end{tabular}

${ }^{a}$ The xylan content value presented does not include the methylglucuronic or acetyl groups as substituents

${ }^{\mathrm{b}}$ Assumes mannose:glucose ratio of 2:1 
Table 2. Pulp yields and kappa numbers from A. altissima kraft cooking

\begin{tabular}{lllll}
\hline Active alkali $\left(\right.$ as $\left.\mathrm{Na}_{2} \mathrm{O}\right)(\%)$ & 14 & 16 & 18 & 20 \\
\hline Total yield $(\%)$ & 55.2 & 54.9 & 54.0 & 52.1 \\
Rejects (\%) & 0.6 & 0.6 & 0.3 & 0.2 \\
Screened yield $(\%)$ & 54.6 & 54.3 & 53.7 & 51.9 \\
Kappa number & 21.6 & 16.0 & 13.9 & 12.6 \\
\hline
\end{tabular}


Table 3. Properties and chemical composition $(\% \mathrm{w} / \mathrm{w})$ of the A. altissima and industrial E. globulus kraft pulps (unbleached and unbeaten pulps with a kappa number of 16)

\begin{tabular}{lcc}
\hline & $\begin{array}{c}\text { A. altissima } \\
\text { kraft pulp }\end{array}$ & $\begin{array}{l}\text { E. globulus } \\
\text { kraft pulp }\end{array}$ \\
\hline Viscosity $\left(\mathrm{cm}^{3} / \mathrm{g}\right)$ & 1110 & 1120 \\
Extractives $(\mathrm{ethanol} /$ toluene $)$ & 0.3 & 0.2 \\
Cellulose & 77.0 & 70.9 \\
Xylan & 11.8 & 17.3 \\
Klason lignin & 1.4 & 1.0 \\
Acid-soluble lignin & 0.8 & 1.0 \\
Total lignin & 2.2 & 2.0 \\
\hline
\end{tabular}


Table 4. Morphological properties of the A. altissima and industrial E. globulus kraft pulp fibers (unbleached and unbeaten pulps with a kappa number of 16)

\begin{tabular}{lll}
\hline & $\begin{array}{l}\text { A. altissima } \\
\text { kraft pulp }\end{array}$ & $\begin{array}{l}\text { E. globulus } \\
\text { kraft pulp }\end{array}$ \\
\hline Fines content $(<0.150 \mathrm{~mm})(\%)$ & 12.2 & 7.7 \\
Fiber length $\left(\mathrm{L}_{\mathrm{n}}\right)(\mathrm{mm})$ & 0.67 & 0.56 \\
Fiber length $\left(\mathrm{L}_{\mathrm{l}}\right)(\mathrm{mm})$ & 0.80 & 0.66 \\
Fiber coarseness $(\mathrm{mg} / \mathrm{m})$ & 0.122 & 0.087 \\
$\mathrm{~N}^{\circ}$ fibers $\left(\times 10^{-6}\right) / \mathrm{g}$ & 10.3 & 17.5 \\
Fiber width $(\mu \mathrm{m})$ & 24.2 & 16 \\
Fiber wall thickness $(\mu \mathrm{m})$ & 4.8 & 2.5 \\
Runkel index & 0.66 & 0.45 \\
\hline
\end{tabular}


Table 5. Papermaking properties of the unbleached (kappa number of 16) A. altissima and E. globulus kraft pulp handsheets

\begin{tabular}{llllll}
\hline & $\begin{array}{l}\text { A. altissima } \\
\text { (AA) kraft } \\
\text { pulp }\end{array}$ & $\begin{array}{l}\text { E. globulus } \\
\text { (EG) kraft } \\
\text { pulp }\end{array}$ & $\begin{array}{l}\text { EG:AA } \\
(50: 50, \mathrm{w} / \mathrm{w})^{\mathrm{a}}\end{array}$ \\
\hline Beating time (rev. PFI) & 0 & 3000 & 0 & 750 & \\
Drainability (SR) & 14 & 31 & 18 & 34 & \\
Basis weight (g/m $\left.{ }^{2}\right)$ & 63.6 & 64.0 & 63.8 & 64.8 & 65.3 \\
Bulk $\left(\mathrm{cm}^{3} / \mathrm{g}\right)$ & 1.99 & 1.42 & 1.65 & 1.53 & 1.45 \\
Air resistance (Gurley, s/100 ml) & 0.7 & 9.0 & 1.8 & 9.5 & 8.2 \\
Roughness (smooth side, & 805 & 165 & 367 & 167 & 164 \\
$\mathrm{~mL} / \mathrm{min})$ & & & & & \\
R457 C & 44.5 & 44.3 & 36.2 & 35.0 & 36.8 \\
Light scattering $\left(\mathrm{m}^{2} / \mathrm{kg}\right)$ & 36 & 23 & 34 & 28 & 25 \\
Opacity $(\%)$ & 95.3 & 90.1 & 96.5 & 95.4 & 93.2 \\
Tensile index $(\mathrm{N} \cdot \mathrm{m} / \mathrm{g})$ & 23.0 & 63.5 & 40.6 & 69.1 & 68.4 \\
Tensile stiffness $(\mathrm{kN} / \mathrm{m})$ & 460 & 615 & 490 & 555 & 560 \\
Elongation $(\%)$ & 0.5 & 2.7 & 1.9 & 3.1 & 3.0 \\
Scott bond $\left(\mathrm{J} / \mathrm{m}^{2}\right)$ & 64 & 321 & 128 & 207 & 259 \\
Burst index $\left(\mathrm{kPa} \cdot \mathrm{m}^{2} / \mathrm{g}\right)$ & 0.68 & 3.67 & 1.71 & 4.28 & 4.19 \\
Tear index $\left(\mathrm{mN} \cdot \mathrm{m}^{2} / \mathrm{g}\right)$ & 2.5 & 7.4 & 5.6 & 9.4 & 8.6 \\
\hline
\end{tabular}

${ }^{a}$ Mixture of refined E. globulus (750 PFI) and A. altissima (3000 PFI) kraft pulps 


\section{Figure captions}

Figure 1. UV-vis $k / s$ spectra of A. altissima (a) and E. globulus pulps (b). 


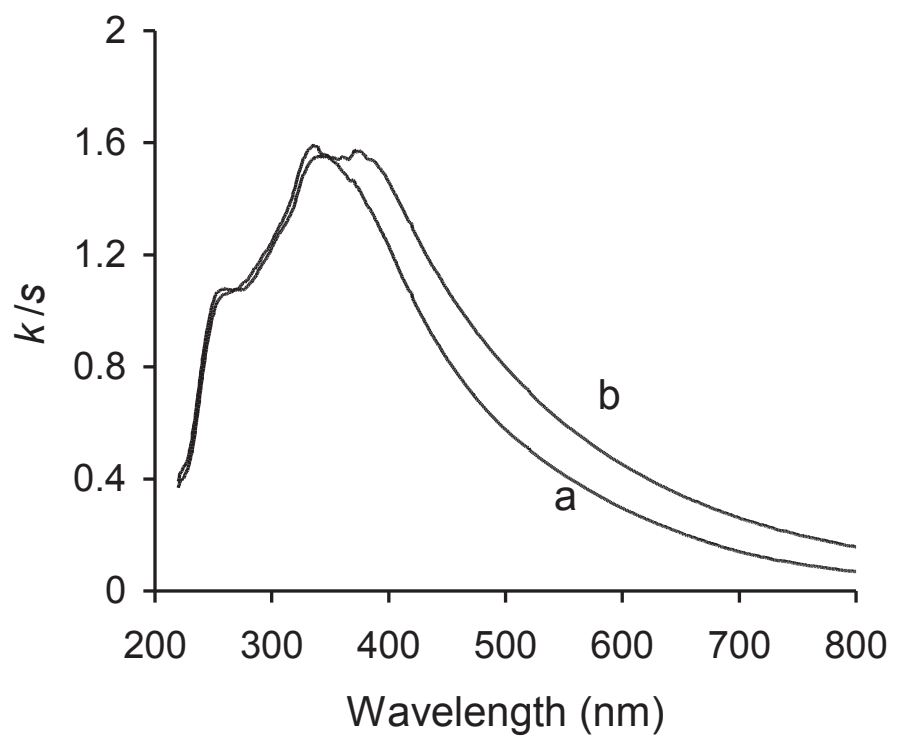

Fig. 1 